\title{
Tuberculosis Patient Adherence to Treatment and Transmission to Home Contact Family Members
}

\author{
Ernawaty Siagian \\ Faculty of Nursing, Universitas Advent Indonesia \\ Email: ernawatysiagian74@yahoo.com
}

\begin{abstract}
Tuberculosis is a contagious disease that remains a health problem worldwide. Treatment of tuberculosis is one of the main strategies in controlling tuberculosis because it can break the transmission chain, especially in families of household contacts where transmission is twice as risky as casual or unfamiliar contact. The purpose of this study was to analyze secondary data on patient adherence to pulmonary tuberculosis treatment sessions and transmission to household contact families in 2016-2017 at a private hospital in Indonesia. This research used a correlative descriptive design with Secondary Data Analysis (ADS) approach using existing data as primary data that is TB 06 and TB 09 data, TB 01 (medical card TB PKM). The population in this research was based on the report of patient data of TB DOTS year 2016-2017 with 60 TB patients. The statistical analysis used was Pearson's r. The result of the research showed that the patient's adherence of pulmonary tuberculosis to treatment sessions. The value of adherence was seen from all respondents of tuberculosis patients which coming to the referral clinic according to the TB 06, and TB 09. As well as the patient's record card at the referral clinic showed all the respondents routinely took the anti tuberculosis medication and completed the treatment as recommended by the doctor. Investigation based on 60 respondents, there is $23.3 \%$ or 14 people diagnosed based on sputums, while remaining 46 people or $76.7 \%$ based on radiology results. Identification of household contact families members found positive sputum smear examination of 5 people (8.3\%) and found to be undergoing tuberculosis treatment as many as 4 people $(6.7 \%)$. The results of this study found a relationship between tuberculosis patient adherence to treatment sessions and transmission to household contact family with P value $0.001(<0.05)$ with a moderate correlation $(\mathrm{r})=0.378 \%$. For further treatment, the nurse includes TB 06 and TB 09 sheets for follow up treatment at the public health service center.
\end{abstract}

Keywords: Family home contact transmission, treatment adheraence, tuberculosis 
Ernawaty Siagian: Tuberculosis Patient Adherence to Treatment and Transmission to Home Contact

\section{Introduction}

Pulmonary tuberculosis is an infectious disease caused by the Mycobacterium tuberculosis bacteria, which most commonly affects the lungs. This disease can be transmitted through droplets (air) from the throat and lungs of people with active respiratory disease (Kemenkes RI, 2014).

Patients with smear positive $\mathrm{TB}$ are a source of transmission of tuberculosis. A cough or sneeze of TB patient will spread germs into the air in the form of droplet nuclei (sputum) . Approximately 3000 sputum are produced in every cough. Sputum that have stayed for long time in a room will increase the possibility of transmission in the TB disease. The amount of spark can be reduced by the presence of ventilation or adequate air flow and the Mycobacterium tuberculosis bacteria will die if it is exposed to direct sunlight. In a dark and humid condition, sputum sparks can last for several hours (Depkes RI, 2008).

Mycobacterium tuberculosis, these bacteria or germs are rod-shaped, with a length of 1-4 um and a thickness of 0.3-0.6 um. Most of these germs are in the form of fat / lipid, so that germs are resistant to acids and are more resistant to chemicals or physical. Another characteristic of these germs is that aerobics like regions with a lot of oxygen, and areas with high oxygen content, namely apical / lung apices. This area is a predilection for Tuberculosis (Somantri, 2009).

The number of germs released from the lungs can affect the transmission capacity of a patient. The more the number of germs or the higher the results of positive smear on the sputum examination of the patient, the higher the transmitting power of the patient. The concentration of sputum in the air and the duration of breathing the air will affect a person to be exposed to the Mycobacterium tuberculosis bacteria (Depkes RI, 2008)

Complaints and symptoms that may indicate that a person is included in the suspicion of pulmonary tuberculosis can be seen from the main symptoms shown. The symptoms are coughing up phlegm for approximately 2-3 weeks, additional symptoms that are often encountered include sputum mixed with blood, persistent fever, shortness of breath, pain in the chest, weakness, decreased appetite, weight loss, and feeling unwell. However, many of the sufferers are not aware of the signs and symptoms that appear (Kemenkes RI, 2014).

Tuberculosis is an infectious disease that is still a problem in the health world until today. The number of new cases of tuberculosis (TB) in 2015 reached 10.4 million people worldwide, increasing from just 9.6 million. After the country of India, Indonesia is the second largest country with tuberculosis sufferers with 1.02 million cases (WHO, 2016).

The number of pulmonary tuberculosis patients is a big problem for developing countries including Indonesia, because it is estimated that $95 \%$ of tuberculosis sufferers are in developing countries, and $75 \%$ of pulmonary tuberculosis sufferers are in productive age groups (15-50 years) (Laban, Y.L, 2008). Pulmonary tuberculosis can occur in all people, but there are several groups that are more at risk for pulmonary tuberculosis, among others due to the presence of comorbidities such as diabetes, kidney failure, heart disease, HIV sufferers, patients who get cancer treatment and malnourished people (Syamsudin, 2013).

The emergency of TB for humanity globally have been declared by WHO since 1993. The burden of TB disease in the community is very high, although the DOTS strategy has proven to be very effective in controlling the spread of this disease. In 2009 the WHO stated that there were still 9.5 million cases of new TB and worldwide the impact of TB was 0.5 million people. TB / HIV co-infection, multi drug resistant TB (MDGs) and other cases with a high degree of complexity are challenges that must be faced by TB disease control efforts. Treatment of tuberculosis is one of the main strategies in controlling tuberculosis because it can break the chain of transmission. In 1995 the national tuberculosis control program began implementing the strategy of Directly Observed Treatment Short Course (DOTS) (Kemenkes RI, 2011).

Nationally implemented in all health care facilities in order to control tuberculosis. Family is the smallest unit of the community consisting of and other family members who gather and live in a household because of 
Ernawaty Siagian: Tuberculosis Patient Adherence to Treatment and Transmission to Home Contact

blood ties and marital ties or an adoption. Between one family and the others, they interact and count on each other. If one or several family members have health problems, it will affect other family members and other families around them (Mubarak, 2009). The closest family of pulmonary tuberculosis sufferers, especially those living at home, are very vulnerable to contracting pulmonary tuberculosis. So there needs to be an effort to prevent transmission to other family members. In handling diseases such as pulmonary $\mathrm{TB}$, the family has a very important role in the healing process of the disease, where family members can provide information about the disease, give moral support, and prevent transmission of the disease (Kemenkes RI, 2011).

Adherence factors, attitudes and actions have a great influence on the health status of individuals and communities and play an important role in determining the success of a disease control program and prevention of transmission of pulmonary tuberculosis. Preventive behavior of transmission that can be carried out by patients with pulmonary tuberculosis, among others, cover the mouth when coughing and sneezing, spitting in a place that has been given disinfectant, avoiding cold air, make sure the sunlight enters their bedroom and foods that are high in carbohydrates and high in protein (Jaji , 2010).

The results of a preliminary study conducted by Sari (2013) which stated that as many as 12 people ( $100 \%$ of 12 respondents) showed symptoms of pulmonary tuberculosis in families who lived at home with patients with pulmonary tuberculosis. This is because families tend to have more frequent time intensity to make direct contact or interact with patients. In addition, families are also difficult to avoid contact because of the responsibility to care for patients. This phenomenon illustrates that there are still many patients with pulmonary TB found in the community. The possibility of transmission has occurred in the smallest unit of the community, namely at the family level. Until 2010 the development of the implementation of the DOTS strategy in which one of them was PMO or supervisor swallowing drugs which were not only carried out by health workers but also by family members of pulmonary TB patients, the role of the family was very influential on the healing process of pulmonary $\mathrm{TB}$ including treatment and supervision.

Nizar (2017) explained several efforts to prevent transmission of pulmonary tuberculosis, namely: treating smear positive pulmonary tuberculosis patients until healed / adhered to treatment. Regular treatment of pulmonary tuberculosis patients by regularly taking medication until it's done with strict supervision. Treatment must be done within six months continuously without interruption until healed, so as to prevent transmission to other people.

Forms used in recording TB in health care facilities which include health centers, hospitals, pulmonary disease treatment centers, clinics and private practice doctors are: List of suspected patients (suspects) filled in by officers at the clinic / BP for dissemination to search for TB suspects (TB .06). The usefulness of form TB 06 is an auxiliary book for TB staffs in UPK who treat patients, and referral forms or transfer patients (TB.09) Use of TB 09 form is used if a patient is referred or moved to a new UPK, The use of form TB 01 card is stored in the health service unit (PKM) where patients get treatment so treatment can be continued with easy The role of Community Health Centers or PKM in Indonesia in implementing the national TB program is no doubt. The Puskesmas has a better community health program infrastructure, so that the drug dropout rate is low. treatment card for TB patients. (Kemenkes RI, 2014).

The purpose of this study was to analyze secondary data on patient adherence to pulmonary tuberculosis treatment sessions and transmission to household contact families in 2016-2017 at a private hospital in Indonesia.

\section{Research Method}

This research is descriptive correlative, with the Secondary Data Analysis (ADS) approach. The population of this study is a report of DOTS 2016-2107 TB patient data in Bandar Lampung Hospital. The sample was 
Ernawaty Siagian: Tuberculosis Patient Adherence to Treatment and Transmission to Home Contact

taken around the Bandar Lampung Adventist Hospital such as Puskesmas Kedaton, Puskesmas Wayhalim and Puskesmas Rajabasa by using convenience sampling technique, which is taking samples on certain considerations or stipulating that the source of the data studied was considered to be representative of 60 data on tuberculosis patients. The sample has the following inclusion criteria: 1) Patients with pulmonary tuberculosis contained in TB DOTS 06 data and given TB referral letter 09 to the puskesmas in 2016-2017, 2) Patients with pulmonary tuberculosis contained in DOTS 06 TB data in the year 2016-2017 which was given a reference sheet of TB sheet 09 to the Puskesmas around the city of Bandar Lampung, and 3) Subjects were tuberculosis patients found in the DOTS TB data of all ages male and female. The sample has an exclusion value: Patients who are given TB 09 referral form outside the city of Bandar Lampung.

Adherence variable, is the attitude or behavior of humans in carrying out rules or work with full awareness to complete the tasks and obligations given. Where with categories: 1) Available in TB data sheet 06, 2) Visiting PKM referrals according to the data contained in TB 06, 3) Attached TB 09 referral health offices, 4) Routine check with Puskesmas, 5) Routinely taking medicines for health centers, 6 ) Completion of 6 months of treatment or until completion according to doctor's advice. 7) Results of supporting examinations based on BTA examination (Kemenkes RI, 2014). Home contact variables, which mean gathering and living in one household due to blood ties and marital ties or an adoption. Where is the category whether there is a family member who has a positive smear examination and whether there is a family member at home who is undergoing TB treatment.

Data collection instruments in this study DOTS TB data on sheets TB 06 and 09 . Secondary data analysis related to compliance of pulmonary tuberculosis patients to treatment sessions based on data containing 7 items of compliance statements, symptoms that arise in the family of household contacts containing 2 items that will be checked $(\sqrt{ })$ by the researcher. which consists of two answer choices, namely: yes, or no, which is taken based on DOTS TB data on TB 06 sheet and the results of checking the researcher to the related health center as a reference, whether the patient continues treatment by submitting a TB 09 sheet to the relevant Puskesmas according to the reference.

The forms used in TB registration in health care facilities which include puskesmas, hospitals, pulmonary disease treatment centers, clinics and private practice doctors are TB 06 which includes a list of suspected patients filled by staff to screen suspects for TB is an aid book for TB officers at the UPK treat patients. Whereas the TB 09 form is a referral form if a patient will be referred. The top part of this form is filled in by staffs from the treatment unit who send the patients. The bottom part filled out by the staffs who receive the referral or transfer of the patient, then sent back to the sending unit so that the sending staffs know that the patient has continued treatment. The use of form TB 01 card is stored in the health service unit (PKM) where patients get treatment. The use of form TB 01 card is stored in the health service unit (PKM) where patients get treatment. This data is found on TB 01 (medical card TB PKM). treatment card for TB 01 patients consisting of; patient identity, history of previous treatment, results of chest X-ray, sputum, description of routine patient examination, routine description of taking OAT, description of completing treatment, description of examination of household contact (sputum) and description of family members undergoing TB treatment (Kemenkes RI, 2014).

To obtain the data, use The forms used in TB registration in health care facilities which include puskesmas, hospitals, pulmonary disease treatment centers, clinics and private practice doctors are TB 06 which includes a list of suspected (suspected) patients filled with officers to screen suspects for TB is an aid book for TB officers at the UPK treat patients. Whereas the TB 09 form is a referral form if a patient will be referred. The top part of this form is filled in by officers from the treatment unit who send patients. The bottom part of the form is filled out by the officer who received the referral or transfer of the patient, then sent back to the sending unit so 
Ernawaty Siagian: Tuberculosis Patient Adherence to Treatment and Transmission to Home Contact

that the sending officer knows that the patient has continued treatment the documentation method: Researchers obtained data from TB DOTS sheets in 2016-2017 in Advent Hospital Bandar Lampung, namely sheet TB 06 as hospital documents and sheet TB 09 which patients took when returning for referral to the nearest health center to obtain follow-up treatment with the following steps: 1) Researchers will sort out patient data contained in TB 06 sheet and classify based on referral to the same health center, 2) After that the researcher will go to the related health center and adjust the data and check whether tuberculosis patients The TB 09 referral letter was sent to the relevant health center to come to continue treatment, and 3) Next the researchers used structured observation, namely observation guidelines that were arranged in detail resembling a check-list.
The researcher just put the $\sqrt{ }$ (check) mark on the appropriate criteria. Interview method: Interviews will be conducted with TB DOTS staffs at Bandar Lampung Adventist hospitals and DOTS TB clinic related to tuberculosis patient data.

All data that has been collected successfully are discussed using descriptive method, using the calculation of univariate frequency analysis, percentage and average. To answer if there is a significant relationship between the compliance of tuberculosis patients with transmission to family of household contacts based on DOTS TB data for 2016-2017, the relationship is analyzed using bivariate analysis relationships, for data ratios using Pearson's r (Grove \& Cipher, 2016).

\section{Research Results}

Table 1 Distribution of Respondent Demographic Data

\begin{tabular}{lccc}
\hline Variable & Years Old & Frequency & Percentage \\
\hline Age & $17-30$ & 22 & 36.7 \\
& $31-40$ & 9 & 15 \\
& $41-50$ & 7 & 11.6 \\
Gender & $51-65$ & 22 & 36.7 \\
& Male & 25 & 41.7 \\
Education & Female & 35 & 58.3 \\
& Elementary & 8 & 13.3 \\
& Secondary & 8 & 13.3 \\
& High School & 33 & 55 \\
Medical History & College & 11 & 18.4 \\
& New & 57 & 95 \\
& Break & 0 & 0 \\
\hline
\end{tabular}

Table 2 Existing Respondents included in the TB Sheet Data 06

\begin{tabular}{|c|c|c|c|c|}
\hline & Frequency & Perent & Valid Percent & $\underset{\text { Percent }}{\text { Cumulative }}$ \\
\hline \multicolumn{5}{|c|}{$\begin{array}{c}\text { Available in TB } 06 \\
\text { data sheet }\end{array}$} \\
\hline Valid Total & 60 & 100.0 & 100.0 & 100.0 \\
\hline
\end{tabular}


Ernawaty Siagian: Tuberculosis Patient Adherence to Treatment and Transmission to Home Contact

Table 3 Comes to PKM as Listed in the TB Sheet 06

\begin{tabular}{|c|c|c|c|c|}
\hline & Frequency & Perent & Valid Percent & $\underset{\text { Percent }}{\text { Cumulative }}$ \\
\hline $\begin{array}{l}\text { Visiting PKN } \\
\text { referral accordir } \\
\text { TB } 06\end{array}$ & & & & \\
\hline Valid Total & 60 & 100.0 & 100.0 & 100.0 \\
\hline
\end{tabular}

Table 4 Attaching TB 09 to the Referral Health Center

\begin{tabular}{ccccc}
\hline $\begin{array}{c}\text { Attach TB 09 to } \\
\text { the referral health } \\
\text { center }\end{array}$ & Frequency & Percent & Valid Percent & $\begin{array}{c}\text { Cumulative } \\
\text { Percent }\end{array}$ \\
\hline Valid Total & 60 & 100.0 & 100.0 & 100.0 \\
\hline
\end{tabular}

Table 5 Overview of Respondents Regularly taking checkup in Health Center, Taking OAT to Health Center, Completing Treatment and Against Investigation of Supporting BTA Results

\begin{tabular}{|c|c|c|c|c|}
\hline & Frequency & Percent & Valid Percent & $\underset{\text { Percent }}{\text { Cumulative }}$ \\
\hline \multicolumn{5}{|c|}{ Routine Checkup/ To see doctor in Public Health Service Center } \\
\hline Valid Total & 60 & 100.0 & 100.0 & 100.0 \\
\hline \multicolumn{5}{|c|}{ Routinely take OAT to the health center } \\
\hline Valid Total & 60 & 100.0 & 100.0 & 100.0 \\
\hline \multicolumn{5}{|c|}{ Complete treatment } \\
\hline Valid Total & 60 & 100.0 & 100.0 & 100.0 \\
\hline \multicolumn{5}{|c|}{ Supporting checks based on the results of BTA } \\
\hline No & 46 & 76.7 & 76.7 & 76.7 \\
\hline Yes & 14 & 23.3 & 23.3 & 100.0 \\
\hline Valid Total & 60 & 100.0 & 100.0 & \\
\hline
\end{tabular}

Table 6 Overview of Family Members at Home Contact with Results of Positive BTA Examination and Who Undergo TB Treatment

\begin{tabular}{|c|c|c|c|c|c|}
\hline \multicolumn{2}{|c|}{$\begin{array}{c}\text { Home contact family members } \\
\text { who are the result of BTA }(+) \\
\text { examination }\end{array}$} & Frequency & Percent & Valid Percent & $\begin{array}{c}\text { Cumulative } \\
\text { Percent }\end{array}$ \\
\hline \multirow[t]{3}{*}{ Valid } & No & 55 & 91.7 & 91.7 & 91.7 \\
\hline & Yes & 5 & 8.3 & 8.3 & 100.0 \\
\hline & Total & 60 & 100.0 & 100.0 & \\
\hline \multicolumn{6}{|c|}{$\begin{array}{c}\text { Family members undergoing TB } \\
\text { treatment }\end{array}$} \\
\hline \multirow[t]{3}{*}{ Valid } & No & 56 & 93.3 & 93.3 & 93.3 \\
\hline & Yes & 4 & 6.7 & 6.7 & 100.0 \\
\hline & Total & 60 & 100.0 & 100.0 & \\
\hline
\end{tabular}


Ernawaty Siagian: Tuberculosis Patient Adherence to Treatment and Transmission to Home Contact

Table 7 Table of Correlation of Compliance with Transmission to Families at Home Contact

\begin{tabular}{cccc}
\hline & & Obidience & $\begin{array}{c}\text { Family in House } \\
\text { Infection }\end{array}$ \\
\hline & Sig. (2-tailed) & 6.003 \\
Obidience & $\mathrm{N}$ & 1 & 60 \\
Home Contact & Pearson Correlation & $0.378^{* *}$ & $0.378^{* *}$ \\
& Pearson Correlation & 0.003 & 1 \\
& Sig (2-tailed) & 60 & 60 \\
\hline
\end{tabular}

The demographic data discussed are demographic data from 60 tuberculosis patients recorded in TB 06 data sheets at Bandar Lampung Adventist Hospital and TB 09 at Kedaton Health Center, Way Halim Health Center and Raja Basa Health Center. The characteristics of demographic profiles shown in this study are age, sex, education and treatment history.

In table 1, It was found that respondents with a new treatment history were 57 people $(95 \%)$, no treatment history was broken, and respondents with a relapse treatment history were 3 people $(5 \%)$.

Based on the data obtained from table 2 , it can be seen that the percentage of TB patients found in TB data sheet 06 , which is 60 people $(100 \%)$. These results indicate that all respondents were recorded in TB sheet 06 . The obedience of government or private health service providers to TB control national guidelines records and reports $\mathrm{TB}$ cases found and or treated according to the prescribed recording format.

Based on the data obtained from table 4, it can be seen that the number of TB patients who visited PKM according to those contained in TB 06 sheet was 60 people $(100 \%)$ with the percentage that all respondents came to PKM referral according to those recorded in TB sheet 06 . Analysis The data above shows that $100 \%$ of clients come to PKM according to those contained in TB sheet 06 . The TB patients do not visit other PKM, they only visit the PKM listed on TB sheet 06 so that PKM staffs can monitor the treatment of TB sufferers.

Based on the data obtained from Table 5, it can be seen that the number of respondents attached TB 09 is 60 people $(100 \%)$ with the percentage that all respondents contained in the TB DOTS data that will be referred to attached to sheet TB 09. Based on data analysis above all respondents $(100 \%)$ attach TB 09 to the Referral Health Center. This shows that all TB patients found at the hospital and allowed to go for medical treatment by a doctor are always included with TB 09 sheet, as a reference and information to the Community Health Centers (PKM) where the patient will continue treatment.

Based on the data obtained from table 5, it can be seen that the number of respondents who routinely check the health center 60 people with a percentage of $100 \%$ stated that all respondents regularly check with the community health centers or puskesmas (PKM). The data analysis above shows all respondents in routine check / treatment data to referral health centers. This shows that respondents can collaborate with PKM officers in undergoing treatment. With collaboration can improve treatment success.

In table 5, it can be seen that all respondents who numbered 60 people $(100 \%)$ routinely took OAT to the health center. From the results of data analysis shows that all respondents regularly take OAT to the health center.

Based on the data obtained in Table 5, it can be seen that the number and percentage of patients with tuberculosis who complete treatment 6 months or until completion according to the doctor's recommendations are 60 people $(100 \%)$. Analysis of the data above shows that all respondents completed treatment according to the doctor's recommendations.

From the results above it was found that out of 60 respondents, only 14 people $(23.3 \%)$ were diagnosed with tuberculosis based on the results of positive smear supporting investigations. The remaining 
Ernawaty Siagian: Tuberculosis Patient Adherence to Treatment and Transmission to Home Contact

46 people $(76.7 \%)$ were based on radiology results. The results of the analysis above state that $23.3 \%$ of respondents found positive smear examination results, and $76.7 \%$ were diagnosed based on thorax X-rays.

The data in table 6 shows that the number of family of household contacts who found positive smear examination results were 5 people $(8.3 \%)$. Then as many as 55 people $(91.7 \%)$ patients with pulmonary tuberculosis found that family home contact from patients did not find a positive smear examination. From the data analysis shows that 5 respondents $(8.3 \%)$ had a family of household contacts with the results of a positive smear examination, while 55 other respondents $(91.7 \%)$ with the results of a negative smear examination. The time TB patients come to PKM bring TB 06 and TB 09 forms. PKM parties will make a patient card specifically for TB management (TB 01).

In the card, a house contact check is listed, where the PKM will visit the house of a TB patient and check the sputum of all household members living with TB patients.

From table 6, it was explained that there were 4 people $(6.7 \%)$ of household contact families who were undergoing TB treatment and 56 people $(93.3 \%)$ did not have family members who were in TB treatment. This means that $93.3 \%$ of the respondents knew about the way to prevent $\mathrm{TB}$ transmission while $6.7 \%$ of the respondents still lacked knowledge about TB transmission.

In the PKM TB management TB 01, there are families of household contacts who are undergoing TB treatment.

Based on the data in table 7, a significant relationship between adherence and transmission to family of household contacts, using bivariate analysis relationships, found a positive moderate correlation statistically $r$ $=0,378$ thus adherence to treatment sessions with transmission to related household contact families. Significant correlations were found between adherence and transmission to family contacts at home. Based on TB patient management cards (TB 01) residing in PKM.

\section{Discussion}

The use of secondary data analysis on TB
06 and TB 09 forms and TB 01 management patient cards at PKM helps explore and find new problems or questions. One important component of surveillance is recording and reporting with the aim of obtaining data that can be processed, analyzed, interpreted, presented and disseminated. The data collected must be accurate, complete and timely so as to facilitate processing and analysis. TB program data is obtained from recording in all health care facilities with one standard system (Kemenkes RI, 2014).

In this study, it was found that all respondents were found in TB sheet 06 . This is in line with the expectations of the National TB Control Program (2011), the compliance of government and private health service providers is required to record and report TB cases found and / or treated according to the recording format which is determined. Data sheet TB 06 is a list of suspects that are filled by officers at the Hospital or poly clinic to capture suspects of TB patients. TB sheet data 06 is done by passive surveillance, through screening in hospitals or treatment centers where tuberculosis sufferers are found first. Variables contained in sheet 06 are closely related to other forms (Nizar, 2017). What must be recorded in the TB 06 sheet form are: serial number, sputum dosage identity number, suspect's name, age and sex, complete address and date and results of sputum examination (Kemenkes RI, 2016).

The results of the study conducted by Nitari (2017) stated that there was a relationship between the level of compliance of pulmonary TB patients with health behaviors (level of knowledge, attitudes and participation of health workers) so it was suggested to be more active in conducting pulmonary $\mathrm{TB}$ counseling in pulmonary $\mathrm{TB}$ patients and their families.

This study shows that all TB sufferers who come to PKM are in accordance with those contained in TB sheet 06 . This shows the role of the community health center (PKM) in Indonesia in implementing the National TB program is undoubted. PKM has a better infrastructure for community health programs, so that the rate of drop-out is low and recovery is high (Depkes RI, 2008).

In this study, the results show that all respondents attach TB 09 to PKM referral. 
Ernawaty Siagian: Tuberculosis Patient Adherence to Treatment and Transmission to Home Contact

This shows that all TB patients found in the hospital and allowed to go for medical treatment by a doctor are always included in TB 09 sheet, as a reference and information to PKM where the patient will continue treatment. Patient referral or transfer form (TB.09). The use of TB 09 form is used if a patient will be referred or moved to a new PKM, so that treatment can be continued easily. The top part of this form is filled by officers from the treatment unit who send the patient. The bottom of the form is filled in by the officer who receives the referral or transfer of the patient, then sends it back to the sending unit so the sending officer knows that the patient has continued treatment. The role of community health centers (PKM) in Indonesia in implementing national TB programs is undoubted. The Health Center has a better community health program infrastructure. So that the drug dropout rate is low (Kemenkes RI, 2016).

In this study it was found that all respondents contained in the data routinely went to the referral Community Health Center. This shows that respondents can work together so as to improve treatment success. Kemenkes RI (2014) explains the purpose of TB treatment is: cure, maintain quality of life and productivity of patients, prevent death due to active TB or follow-up effects, prevent TB recurrence, reduce TB transmission to others and prevent the development and transmission of drug resistant.

In this study it was found that all routine respondents took OAT to the Community Health Center. By routinely taking medicine to PKM, respondents are expected to understand the importance of taking medication regularly so as to avoid drug resistance. Taking medication regularly and precisely in the intensive phase (first 2 months) of infectious patients is not contagious within 2 weeks. The majority of smear positive TB becomes negative smear (conversion) at the end of intensive treatment (Dinkes RI, 2008)

Depkes RI (2008) divides the types of antituberculosis drugs and recommends fixeddose combination drugs (KDT) to reduce the occurrence of drug-resistant TB due to monotherapy. OAT guidelines are provided in the form of combipak packages, with the aim of facilitating drug administration and ensuring continuity of treatment until finished. Anti-tuberculosis drugs (OAT) are given in a combination of several types, in sufficient quantities and in the right dose for 6-8 months so that all germs (including persistent) can be killed.

In this study it was found that all respondents completed treatment according to the doctor's recommendation. In the Indonesian Health Profile, it was found that in 2015 the successful rate of Indonesian medicine was $85 \%$. From this data it was also found that the treatment success rate per province was highest in Lampung with a percentage of $95.2 \%$ and the lowest in Central Kalimantan with $39.2 \%$ (Kemenkes RI, 2014).

In this study it was found that $23.3 \%$ of respondents found positive smear examination results, and $76.7 \%$ were diagnosed based on thorax X-ray results. This is not in accordance with what is expected in the Tuberculosis Control Module (2011) that the diagnosis of tuberculosis is established through direct microscopic examination of sputum. Microscopic examination of phlegm is the most efficient, easy, and inexpensive examination. Sputum examination in the tuberculosis program aims to establish a diagnosis, assess the progress or success of treatment and determine the level of transmission. According Kemenkes RI (2011) The percentage of bacteriologically confirmed pulmonary tuberculosis patients among all patients with recorded pulmonary tuberculosis (bacteorological and clinical), is an indicator that describes the priority of finding tuberculosis patients. This figure is at least $70 \%$, if it is much lower, it means that the diagnosis does not give priority to finding infectious patients.

In this study it was found that showed 5 respondents $(8.3 \%)$ had a family of household contacts with the results of a positive smear examination, while 55 other respondents $(91.7 \%)$ with negative smear examination results. According to Widoyono (2008), the closest family of pulmonary tuberculosis sufferers, especially those living at home, are very vulnerable to contracting pulmonary tuberculosis. So there needs to be an effort to prevent transmission to other family members. A patient with pulmonary tuberculosis with 
Ernawaty Siagian: Tuberculosis Patient Adherence to Treatment and Transmission to Home Contact

positive smear has the potential to transmit to 10-15 people around him per year, so that the likelihood of each contact being infected with pulmonary tuberculosis is $17 \%$. The results of other studies report that the closest contacts (such as family households) will be twice as risky as regular contacts / not at home.

The use of form TB 01 card is stored in the health service unit (PKM) where patients get treatment. The use of form TB 01 card is stored in the health service unit (PKM) where patients get treatment (Kemenkes RI, 2014).

In this study, it was found that there were 4 people $(6.7 \%)$ of household contact families who were undergoing TB treatment and 56 people $(93.3 \%)$ did not have family members who were in TB treatment. This means that $93.3 \%$ of the respondents knew about the way to prevent TB transmission while $6.7 \%$ of the respondents still lacked knowledge about TB transmission. Pulmonary TB disease is very susceptible to transmission to people closest to the patient, such as the family of pulmonary tuberculosis patients so that efforts are needed to prevent transmission to other family members.

Sunlight can kill bacterial diseases, viruses, and fungi, this is very useful for the treatment of tuberculosis. The bacteria in the air can be destroyed by the sun in a short time. The initial level of prevention of transmission of pulmonary TB can be done by sputum sterilization, bed sheets, pillowcases and so on. This sterilization is carried out by direct sun exposure to kill TB germs in 5 minutes. Advise the patient to cover his mouth with a handkerchief when coughing or sneezing, and not spitting on the floor or any place. When coughing, pulmonary tuberculosis sufferers can release 3000 droplet nuclei from tuberculosis bacteria, for when the patient closes his mouth with a handkerchief when coughing can prevent or reduce tuberculosis germs that come out and float in the air so it will reduce the risk of transmission to people around tuberculosis patients. Socio-economic improvement for example: improvement of housing and the environment. Make sure the house has windows and doors wide enough for free sunlight to enter. Ultraviolet light from the sun can kill tuberculosis germs which may be hiding inside the house. Applying a healthy lifestyle in the family', routinely consuming nutritious food, exercising regularly, not smoking and not drinking alcohol. Provide immunization to newborns, no longer than two months old. Tuberculosis vaccine known as BCG can provide active immunity against tuberculosis. Drying mattresses and pillows regularly. If one family member is already infected. Dry the patient's bed under direct sunlight to kill the bacteria Mycro bacterium tuberculosis. Use sputum shelters such as cans or the like that have a lid and have been given karbol / Lysol, so it will kill tuberculosis bacteria and reduce the spread of tuberculosis germs in the free air because it has been accommodated in a closed container (Kemenkes RI, 2016).

In this study it was found that the correlation data between adherence of tuberculosis patients with transmission to the household of household contact was found to be a moderate positive correlation statistically $\mathrm{r}=0,378$ thus adherence to treatment sessions with transmission to related household contacts. Tuberculosis treatment is closely related to medication adherence; the two things are interconnected. The role of the closest family of pulmonary tuberculosis sufferers, especially those who live at home is very susceptible to contracting pulmonary tuberculosis (Jaji, 2010). So there needs to be an effort to prevent transmission to other family members.

Nizar (2017) formulates the factors related to the cure or success of treatment of pulmonary tuberculosis patients in 4 pillars of treatment paradigm, namely: Health service factors: TB management, coordination between health service units, staff training, OAT supply and adequate logistics and health facility location, socio-cultural and economic factors: level of education, employment / income, density of family members, availability of alternative treatments, disease and treatment relationship factors: severity of illness, quality of health services (home visits, counseling, PMO, monitoring and cross check. service: high transportation, distance of house to health facilities, length of waiting for lab examination results, and characteristics of patients: age, sex, education, nutritional status / immune system and type of TB patient. 
Ernawaty Siagian: Tuberculosis Patient Adherence to Treatment and Transmission to Home Contact

According to Kemenkes RI (2016) The objectives of TB treatment include: healing, maintaining quality of life and productivity of patients, preventing death due to active TB or advanced effects, preventing TB recurrence, preventing $\mathrm{TB}$ transmission to others and preventing the development and transmission of drug resistant drugs.

\section{Conclusion}

Based on the results of research conducted on secondary data analysis adherence to tuberculosis patients to treatment sessions and transmission to family home contact at Advent Hospital in 2016-2017, it can be concluded that all TB patients contained in the DOTS TB data were obedient in undergoing good treatment in terms of routinely check with the Community Health Center, routinely take anti-tuberculosis drugs (OAT) and finish treatment until complete. Patients with tuberculosis are included in the DOTS TB data, namely sheets TB 06 and TB 09. Researcher's suggestion is in Discharge Planning Patient, the nurse includes TB 06 and TB 09 sheets for follow-up treatment at the public health service center.

\section{References}

Departemen Kesehatan Republik Indonesia. (2008). Modul Pelatihan Penanggulangan Tuberkulosis, Pengendalian Penyakit dan Penyehatan Lingkungan. Jakarta.

Departemen Kesehatan Republik Indonesia. (2008). Pedoman penanggulangan nasional TB Paru Edisi 2 Cetakan kedua. Jakarta: Ditjen PP\&PL.

Groves, R.M.,Fowler, F, J,. Coupe, M. P,.Lepkowski, J. M., Singe, E.,\& Tourangeau, R. (2009). Survey Methodology, Canada: John Wiley \&s Sons.

Jaji. (2010). Makalah: Peran Keperawatan Komunitas Dalam Peningkatan Derajat kesehatan Masyarakat Menuju MDGs 2015. Universitas Sriwijaya
Kemenkes,R.I.(2011). Profil Kesehatan Indonesia tahun 2010. www.depkes. go.id/index.php/component/.../index.php/ diaksestanggal 20 Februari 2015

Kementerian Kesehatan Republik Indonesia. (2014). Pedoman Naional Pelayanan Kedokteran Tata Laksana Tuberkulosis. Jakarta.

Mubarak, Wahid Iqbal, Nurul Chayatin, Khoirul Rozikin, dan Supradi. (2009). Promosi Kesehatan. Yogyakarta: Graha Ilmu.

Nizar, M. (2017). Pemberantasan dan Penularan Tuberkulosis. Yogyakarta: Gosyen Publishing.

Somantri, Irman. (2009). Asuhan Keperawatan pada Pasien Dengan Gangguan Sistem Pernafasan. Jakarta: Salemba Medika.

Syamsyudin M dan Kebansesilia A. (2013). Buku Ajar Farmakoterapi dan Ganguan Saluran Pernapasan. Jakarta: Salemba Medika.

Widoyono. (2008). Penyakit Tropis, Epidemiologi Penularan, Pencegahan dan Pemberantasanya. Jakarta: Erlangga.

World Healt Organization. (2016). Health Topics Tubeculosis (TB). World Health Organization. hhtp//www.who.int/topics/ tuberculosis/ 5 November 2017 20:00.

Laban, Y. L. (2008). Penyakit dan Cara Pencegahanya Tuberkulosis. Yogyakarta: Kanisius.

Kemenkes Republik Indonesia. (2014). Strategi nasional pengendalian $T B$ di Indonesia 2010-2014. Dirjen PP \& PL. Jakarta; 2011.hlm.12-30.

Departemen Kesehatan Republik Indonesia. Pedoman nasional penangggulangan tuberkulosis. Direktorat Jenderal Pengendalian Penyakit dan Penyehatan Lingkungan. Jakarta; 2011.hlm.2-30.

Nitari Rahmi. (2017). Hubungan Tingkat Kepatuhan Penserita Tuberkulosis Paru 
Ernawaty Siagian: Tuberculosis Patient Adherence to Treatment and Transmission to Home Contact

dengan Perilaku Kesehatan, Efek Samping OAT dan Peran PMO pada Pengobatan, fase Intensif di Puskesmas Seberang Padang 2012-2013. Jurnal Kesehatan Andalas, 6(2). 